\title{
Peningkatan Keterampilan Pembuatan Buku Ajar Matematika SD Pada Mahasiswa Prodi PGSD Universitas Peradaban
}

\author{
Adi Candra Kusuma ${ }^{* 1}$, Arif Rakhman ${ }^{2}$ \\ 1,2Politeknik Harapan Bersama; Jalan Mataram No 9 Pesurungan Lor - Tegal 0283 - 352000 \\ ${ }^{3}$ Program Studi DIII Teknik Komputer \\ e-mail : ${ }^{* 1}$ candraraden45@gmail.com, ${ }^{2}$ cakrakirana7@gmail.com
}

\begin{abstract}
Abstrak
Buku ajar merupakan salah satu sarana keberhasilan proses belajar mengajar. Buku ajar merupakan suatu kesatuan unit pembelajaran yang berisi informasi, pembahasan serta evaluasi. Buku ajar yang tersusun secara sistematis akan mempermudah peserta didik dalam materi sehingga mendukung ketercapaian tujuan pembelajaran. Universitas Peradaban melalui Program Studi PGSD mempunyai harapan dapat mencetak lulusan calon guru yang kompeten dibidangnya. Salah satu yang harus bisa dikuasai oleh mahasiswa ini sebagai calon guru adalah maтри membuat instrumen pendukung pembelajaran diantaranya adalah buku ajar. Hasil dari kegiatan pelatihan pembuatan buku ajar memberikan pengetahuan ilmu, meningkatkan ketrampilan dan melatih pemikiran kreatif mahasiswa dalam menyusun instrumen pembelajaran. Hal ini memberikan dampak yang baik seperti materi, pembelajaran yang ingin disampaikan sesuai dengan alur yang diinginkan, mengetahui bagian penting yang perlu ditekankan pada materi tertentu, dan dapat mengkondisikan kelas sesuai dengan pembelajaran guru.
\end{abstract}

Kata Kunci : Buku ajar, Mahasiswa, Universitas Peradaban

\section{PENDAHULUAN}

Universitas Peradaban merupakan salah satu perguruan tinggi swasta yang terletak di Jalan Raya Pagojengan KM 3, Kecamatan Paguyangan Kabupaten Brebes. Kampus ini memiliki 4 Fakultas diantaranya Fakultas Keguruan dan Ilmu Pendidikan (FKIP) terdapat jurusan PGSD. Kampus ini mempunyai harapan dapat mencetak lulusan calon guru yang kompeten dibidangnya. Salah satu yang harus bisa dikuasai oleh mahasiswa ini sebagai calon guru adalah mampu membuat instrumen pendukung pembelajaran diantaranya adalah buku ajar. kepentingan pembelajaran saat ini, bahan pembelajaran yang akan dikembangkan lebih cenderung pada bahan pembelajaran yang berbentuk tercetak [1].

Buku ajar merupakan salah satu sarana keberhasilan proses belajar mengajar. Buku ajar merupakan suatu kesatuan unit pembelajaran yang berisi informasi, pembahasan serta evaluasi. Buku ajar yang tersusun secara sistematis akan mempermudah peserta didik dalam materi sehingga mendukung ketercapaian tujuan pembelajaran [2]. Maka dari itu, buku ajar harus disusun secara sistematis, menarik, aspek keterbacaan tinggi, mudah dicerna, dan mematuhi aturan penulisan yang berlaku. Jika seorang guru mampu membuat buku ajar sendiri maka buku yang akan disusun akan menyesuaikan dengan karakteristik dan lingkungan kelas yang diampunya, hal ini memberikan dampak yang baik seperti materi, pembelajaran yang ingin disampaikan sesuai dengan alur yang diinginkan, mengetahui bagian penting yang perlu ditekankan pada materi tertentu, dan dapat mengkondisikan kelas sesuai dengan pembelajaran guru. 
Buku ajar termasuk salah satu buku pelajaran. Buku pelajaran yang dimaksudadalah karya tulis yang digunakan guru dalam proses belajar mengajar, makasemua karya tulis tersebut termasuk buku pelajaran. Buku ajar adalah sebuahkarya tulis yang berbentuk buku yang digunakan oleh guru dalam proses belajar mengajar [3]. Berdasarkan definisi buku ajar di atas, maka disimpulkan bahwa yang dimaksud buku ajar adalah sebuah karya tulis yang berbentuk buku dalam bidang tertentu,yang merupakan buku standar yang digunakan guru dan siswa dalam proses belajar mengajar untuk maksud-maksud dan tujuan instruksional, yang dilengkapidengan sarana-sarana pengajaran yang serasi dan mudah dipahami oleh pemakainya di sekolah-sekolah dan perguruan tinggi sehingga dapat menunjang progampengajaran

Buku ajar dirancang sesuai dengan kurikulum, namun hubungan ini tidak bersifat kaku. Kurikulum tidak bersifat menentukan segala sesuatu. Kurikulum masih memerlukan penafsiran, penjelasan, perincian, perlengkapan, pengayaan, dan pemanduan terhadap kompetensi, hasil belajar, indikator, dan materi pokok. Dalam menyusun buku ajar, seorang penulis perlu mempersiapkan silabus dan metode pembelajaran, dan mempersiapkan bahan-bahan serta cara penyajiannya, yang tidak dicantumkan dalam kurikulum.

Salah satu landasan penyusunan buku ajar adalah keilmuan mata kuliah tertentu.Pertanyaan yang harus diajukan ketika merancang buku ajar adalah mata kuliahberada di ranah ilmu apa. Dengan mengetahui landasan keilmuan, maka mudahbagi penulis untuk mengetahui cakupan serta susunan buku ajar yang hendakditulis. Penafsiran terhadap materi dalam kurikulum pun, pada tahap ini, dilakukandari struktur keilmuan yang digunakan. Misalnya, mata kuliah KemahiranBerbahasa Indonesia berada dalam ranah keilmuan Bahasa Indonesia. Atau matakuliah Pengambilan Keputusan, misalnya, akan berada dalam ranah keilmuan Teoridan Perilaku Organisasi. Disiplin yang terakhir adalah disiplin gabungan sejumlahilmu seperti Psikologi dan Sosiologi.

Landasan selanjutnya adalah keterbacaan materi dan bahasa yang digunakan. Hal-hal yang harus dipahami dalam penyusunan buku ajar terkait dengan bagaimana materi harus diolah agar memberikan kemudahan bagi mahasiswa untukmemahaminya, dan bagaimana panjang dan susunan kata, frasa, kalimat, danwacana tidak menyulitkan mereka. Buku ajar yang memberi kemudahan kepadamahasiswa disebut sebagai buku ajar yang mempunyai tingkat keterbacaan yangtinggi. Sebaliknya, buku ajar yang menimbulkan kesulitan kepada mahasiswa untukmemahaminya disebut sebagai buku ajar yang mempunyai keterbacaan rendah.Dengan demikian, penting sekali untuk merancang buku ajar berbasis prinsip komunikatif. Proses penyusunan buku ajar sekolah atau mata kuliah tertentu akan melalui beberapatahap sebagai berikut [3].yaitu Telaah kurikulum, penyusunan silabus, Pengorganisasian buku, Pemilihan materi, Penyajian materi, Penyajian materi merupakan panduan terhadap cara menyajikan materi yang terdapat didalam buku ajar dan Penggunaan bahasa dan keterbacaan.

Menurut Majid sebuah bahanajar minimal harus memuatseperti: (1) petunjukdasar (petunjuksiswa/guru), (2) kompetensi yang dicapai, (3) informasi pendukung, (4) latihanlatihan, (5) petunjuk kerja dapat berupa lembar kerja, dan (6) evaluasi. Bahan ajar disusun dengan tujuan untuk (1) membantu siswa dalam mempelajari sesuatu, (2) memudahkan guru dalam pembelajaran, (3) agar kegiatan pembelajaran menjadi lebih menarik, dan (4) menyediakan berbagai jenis pilihan bahan ajar. [4]. Salah satu model dalam pengembangan bahan ajar adalah Four-D Model Thiagarajan dkk, (dalam Vinta, 2011), yang meliputi tahap pendefinisian (define), perancangan (design), pengembangan (develop), dan pendiseminasian(disseminate).

\section{METODE}

\subsection{Sasaran Kegiatan PKM}

Khalayak sasaran yang dipilih adalah Universitas Peradaban dimana perguruan tinggi swasta yang terdiri dari berbagai fakultas. Pelatihan ini ditunjukan untuk Fakultas Keguruan dan 
Ilmu Pendidikan program studi PGSD Universitas Peradaban Semester 4 yaitu kelas PGSD 1 dan PGSD 2.

2.2. Metode Kegiatan

Kegiatan berupa pelatihan pembuatan buku ajar matematika, dari mulai menelaah kurikulum sampai dengan proses pengguanan bahasa dan keterbacaan. Selama praktek pelatihan buku ajar matematika masing-masing mahasiswa dibagi menjadi beberapa kelompok, yang kemudian masing-masing kelompok memperoleh materi matematika SD yang berbeda dengan kelompok lainnya.

2.3. Kerangka Pemecahan Masalah

Alternatif pemecahan masalah dilakukan pelatihan pembuatan buku ajar matematika mahasiswa prodi PGSD Universitas Peradaban sebagai solusi bagi calon guru untuk mampu membuat instrumen pembelajaran demi mendukung ketercapaian tujuan pembelajaran.

2.4. Tahapan Kegiatan PKM

Dalam merealisasikan pemecahan masalah yang dilakukan terdapat beberapa hal yang dilakukan, diantaranya:

\subsubsection{Persiapan Kegiatan Pengabdian Masyarakat}

Sebelum kegiatan dilaksanakan maka dilakukan persiapan-persiapan sebagai berikut (1) Melakukan observasi dan wawancara terhadap kebutuhan mahasiswa PGSD, (2) Menemukan masalah yang dialami mahasiswa PGSD khususnya kesulitan pembuatan buku ajar, (3) Merancang solusi masalah yang dialami mahasiswa PGSD, (4) Mempersiapkan kebutuhan untuk pelatihan pembuatan buku ajar matematika, (5) Menentukan waktu pelaksanaan dan lamanya kegiatan pengabdian masyarakat

2.4.2. Pelaksanaan Kegiatan Pengabdian Masyarakat

Adapun kegiatan IbM dalam bentuk pelatihan ini dilaksanakan selama 2 hari dan diikuti oleh 62 peserta pada tanggal 1- 2 April 2016; Waktu pukul 08.00 sampai 11.00 WIB bertempat di ruang kelas Universitas Peradaban.

2.4.3. Evaluasi kegiatan

Berdsarkan wawancara, tanya jawab dan pengamatan langsung selama kegiatan pelatihan berlangsung memberikan hasil sebagai berikut memberikan pengetahuan ilmu, meningkatkan ketrampilan dan melatih pemikiran kreatif mahasiswa dalam menyusun instrumen pembelajaran

3.1 Kegiatan pelatihan

\section{HASIL DAN PEMBAHASAN}

Adapun Materi yang Disampaikan pada kegiatan pengabdian masyarakat yaitu pengertian Buku Ajar, Pentingnya Buku Ajar, Landasan Penyusunan Buku Ajar dan Proses Penulisan Buku Ajar

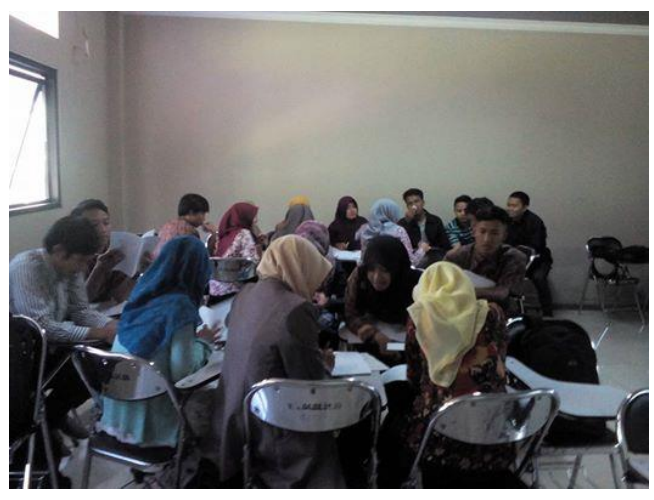

Gambar 1. Kegiatan Pelatihan dibuat Kelompok untuk mendiskusikan/merancang konsep buku yang akan dibuat 


\subsection{Pendampingan Program}

Dengan metode presentasi dan diskusi serta praktek melaluin pendampingan terhadap peserta kegiatan, dengan tujuan output yang dihasilkan mahasiswa mampu membuat sampel buku ajar minimal berisikan 1 pokok bahasan/topik matematika tiap kelompok. Berbagai kreatifitas produk pembuatan buku ajar yang dihasilkan dengan materi matematika SD seperti bilangan, KPK \& FPB, Perbandingan \& Skala, Bangun datar, bangun ruang, statitika, pangkat dan akar pangkat, Garis \& Kurva, Sistem Koordinat, Pengukuran dan Debit. Beberapa hal yang menjadi faktor pendukung pada kegiatan pelatihan ini adalah (a) Peserta kegiatan sangat antusias/ motivasi mengikuti kegiatan ini sampai selesai, (b) Peserta mempunyai rasa keingintahuan tinggi terhadap materi ini dan (c) Peserta mau diberikan arahan dan bimbingan saat pelatihan. Adapun Faktor Penghambat pada kegiatan pelatihan ini adalah (a) Waktu kurang memadai, karena pelatihan sangat singkat dengan materi yang cukup padat, (b) Menentukan waktu pelaksanaan pelatihan pembuatan buku ajar dikarenakan berbenturan dengan waktu aktif kuliah mahasiswa, (c) Perlu ada workshop sehingga dapat memberikan pengetahuan lebih jauh tentang buku ajar pembelajaran dan (d) Peserta yang cukup banyak, membuat keadaan cukup berisik.

\subsection{Capaian Kegiatan}

Pelatihan pembuatan buku ajar matematika merupakan hal baru bagi mahasiswa PGSD Universitas Peradaban, berdasarkan wawancara, tanya jawab dan pengamatan langsung terhadap peserta terlihat sangat antusias mengikuti pelatihan ini. Peserta merasa memperoleh informasi pengetahuan baru sebagai bekal kelak mereka ketika menjadi guru. Tidak kalah pentingnya, Peserta menyadari bahwa buku ajar harus berfungsi sebagai penarik minat dan motivasi peserta didik dan pembacanya. Motivasi pembaca bisa timbul karena bahasa yang sederhana, mengalir dan mudah dipahami. Motivasi bisa timbul karena banyak gagasan dan ideide baru. Motivasi bisa timbul, karena buku ajartersebut mengandung berbagai informasi yang relevan dengan kebutuhan belajarpeserta didik dan pembaca. Namun dalam penelitian ini tidak akan dibahas lebihjauh tentang ini tetapi difokuskan kepada kelayakan buku ajarnya saja.

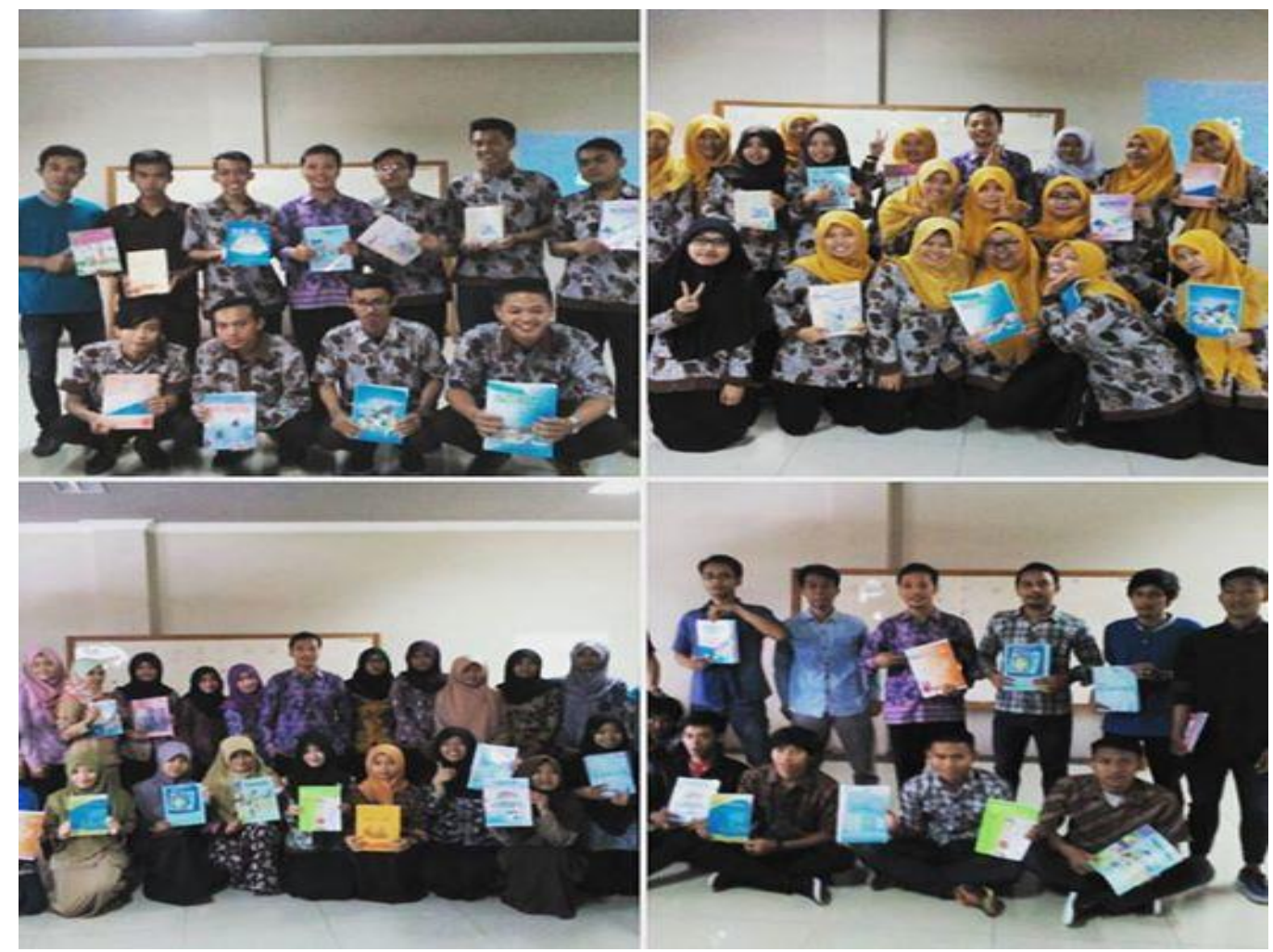

Gambar 2 Kelompok Buku ajar matematika SD 


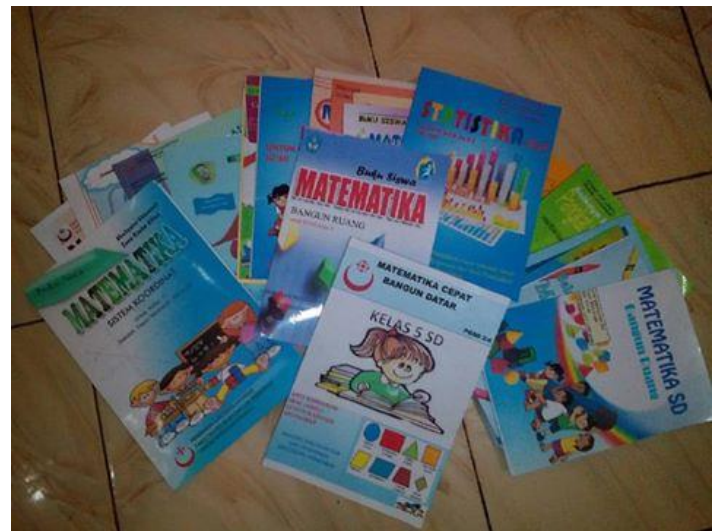

Gambar 3 Hasil Buku ajar yang dibuat masing-masing kelompok

\section{KESIMPULAN}

Adapun hasil kesimpulan kegiatan pengabdian masyarakat sebagai berikut Pengetahuan dan pemahaman mahasiswa PGSD Universitas Peradaban perkembangan mengenai intrumen penunjang pembelajaran (buku ajar) lebih baik. Keingintahuan siswa akan pembuatan buku ajar matematika bertambah dan mendapatkan respon yang baik dalam mendengarkan pemaparan materi yang disampaikan.

\section{SARAN}

Adapun saran dari hasil kegiatan pengabdian masyarakat sebagai berikut Adanya pelatihan yang berkelanjutan, sehingga pemahaman mahasiswa mengenai intrumen lain penunjang pembelajaran selain buku ajar seperti LKS, RPP lebih baik lagi.Waktu pelatihan diperpanjang sehingga siswa lebih banyak mendapatkan materi tentang pembuatan buku ajar. Pendampingan perludilakukanselama pelatihan dan penggunaan buku ajar. Materi buku ajar yang dibuat lebih banyak lagi bahasan yang dikaji

\section{UCAPAN TERIMA KASIH}

Terima kasih kepada Program Studi PGSD Universitas Peradaban yang sudah menyediakan tempat dan peserta pelatihan, Pusat Penelitian dan Pengabdian Masyarakat (P3M) Politeknik Harapan Bersamategal yang telah membantu administrasi dan arahan pelatihan kegiatan pengabdian ini

\section{DAFTAR PUSTAKA}

[1] Djauhar Sidiq, dkk. 2008. Pengembangan Bahan Ajar. Jakarta: Direktorat Jenderal Pendidikan Tinggi Depdiknas

[2] Hanifah, Umi. 2014. Pentingnya Buku Ajar Yang Berkualitas Dalam Meningkatkan Efektivitas Pembelajaran Bahasa Arab. Surabaya: Jurnal Ilmu Terbiyah At-Tajdid UIN Sunan Ampel. Vol 3 No.1.

[3] Departemen Pendidikan Nasional. (2005). PedomanPenulisan Buku Pelajaran: Penjelasan Standar Mutu Buku Pelajaran Bahasa dan Sastra Indonesia. Departemen Pendidikan Nasional. Jakarta

[4] Majid, A. 2008. Perencanaan Pembelajaran. Bandung: Rosdakarya.

[5] Tiarani A, Vinta. 2011. Teknik Pengembangan Bhan Ajar Dwi Bahasa untuk Kelas Internasional. Yogyakarta: UNY. 